\title{
Statutory health insurance competition in Europe: a four-country comparison
}

\author{
Sarah Thomson ${ }^{\mathrm{a}}$, Reinhard Busse ${ }^{\mathrm{b}}$, Luca Crivelli ${ }^{\mathrm{c}}$, Wynand van de Ven ${ }^{\mathrm{d}}$, Carine \\ Van de Voorde ${ }^{e}$
}

\begin{abstract}
This article considers the potential for insurer competition to improve health system performance by strengthening purchasing. Economic theory suggests that insurer competition will enhance efficiency if: (1) people have free choice of insurer, (2) competition is based on price and quality rather than risk selection and (3) insurers have tools to influence health care costs and quality. The article assesses the extent to which these assumptions hold in Belgium, Germany, the Netherlands and Switzerland. It finds that health insurance market reforms in these countries have had mixed results in fulfilling these assumptions. In spite of significant investment in risk equalisation, incentives for risk selection remain. Consumer mobility is lower among older and chronically ill people, possibly due to close interaction between statutory and voluntary coverage. Although insurers in some countries increasingly have tools to enhance value, they may not always use them. The analysis suggests that the instrumental value of insurer competition rests on multiple assumptions that can only be upheld through frequently complex interventions often requiring elusive data. Making it work therefore requires action on several fronts, particularly to ensure incentives are aligned across the health system, and awareness of the political nature of some barriers to success.
\end{abstract}

Key words: health insurance, choice, competition, Europe

${ }^{\mathrm{a}}$ LSE Health and European Observatory on Health Systems and Policies, LSE Health (COW3.01), Houghton Street, London WC2A 2AE, United Kingdom, e-mail:

s.thomson@lse.ac.uk

${ }^{\mathrm{b}}$ Berlin University of Technology, Dept. Health Care Management, Strasse des 17. Juni 135, 10623 Berlin, Germany, email: rbusse@tu-berlin.de

c Università della Svizzera italiana, Faculty of Economics, Via Buffi 13, 6900 Lugano, Switzerland, e-mail: luca.crivelli@usi.ch

${ }^{\mathrm{d}}$ Erasmus University Rotterdam, Burgemeester Oudlaan 50, 3000 DR Rotterdam, email: vandeven@bmg.eur.nl

${ }^{\text {e }}$ Catholic University Leuven, Naamsestraat 69, 3000 Leuven, Belgium, e-mail: carine.vandevoorde@econ.kuleuven.be 


\section{The rationale for competition among statutory health insurers}

Choice of and competition among insurers offering statutory (mandatory) health coverage has become more prominent in Europe in the last 15 years and is now an integral feature of health financing policy in Belgium, the Czech Republic, Georgia, Germany, the Netherlands, the Russian Federation, Switzerland and Slovakia $(1,2)$. Although this form of competition is not widespread in practice, the idea that thirdparty payers should compete for publicly financed clients is debated in countries as diverse as England and Estonia (3, 4).

In theory, competition between insurers is intended to enhance allocative and productive efficiency in health care administration and delivery through two mechanisms: making insurers bear financial risk and giving people free choice of insurer (5). Having a fixed and prospectively determined budget within which to meet enrolee health care costs may encourage insurers to use resources judiciously; if they cannot stay within budget they will have to charge higher premiums and risk losing enrolees. The threat of consumer exit may also encourage insurers to be more responsive to public preferences; if people are sensitive to price and quality, insurers will try to maintain or improve quality while minimising costs using a range of tools, including cutting overheads and engaging in more 'strategic' purchasing of health services (6). At least three other conditions must be met for insurer competition to achieve efficiency objectives ${ }^{1}$. First, people should be able to choose and switch insurer with ease and without incurring significant transaction costs. This implies that individuals are able to make an informed choice of insurer and do not face barriers to switching. Second, insurer competition should be based on price and quality, rather than risk selection (7). Third, insurers should have access to tools that allow them to influence health care quality and costs, and be willing to use them.

In practice, European countries have introduced choice of insurer in response to a range of problems with existing statutory health insurance arrangements. Some countries have explicitly pursued efficiency goals. Others have been driven more by concerns for equity, access and expenditure control. Even where efficiency has not been a stated or primary rationale, however, those in favour of insurer choice may have expected competition to result in efficiency gains and, ultimately, to improve health system performance. In addition to differences in goals, there are also differences in key aspects of health insurance market reform in European health systems - for example, Dutch insurers have access to many more efficiency-enhancing tools than do their counterparts in other countries (see below). This cross-national variation in goals and in implementation prompts three observations. First, differences in implementation may be linked to differences in goals. Second, there is little evidence to suggest that health insurance competition has had the desired effect on efficiency, even where efficiency has been an explicit goal (8). For example, recent evaluations of the 2006 health insurance market reform in the Netherlands report mixed results: waiting times for

\footnotetext{
${ }^{1}$ Bevan and van de Ven (2010) have set out a larger number of conditions that must be fulfilled if insurer competition is to achieve its goals. We have condensed some of these conditions so that they fall under the three conditions listed here. We also take some of the conditions in Bevan and van de Ven's list, such as regulation, as a given since (for example) universal freedom to switch could probably only be achieved through regulation.
} 
inpatient treatment and pharmaceutical prices have fallen (9), but so far only some aspects of health insurer performance have improved (the transparency of user charges requirements and health plan information) (10). Third, expectations about efficiency gains may conflict with other stated objectives such as expenditure caps or expenditure control.

This paper explores differences in the goals and implementation of statutory health insurance competition in Europe. To do so it compares the experience of four western European countries (Belgium, Germany, the Netherlands and Switzerland), focusing on these countries because of their similar health system characteristics and economic and political context. The paper's analysis is structured as follows. The next section outlines the policy goals underpinning statutory health insurance reforms in each country. Subsequent sections review the implementation and development of policies to ensure consumer mobility, remove incentives for risk selection and give insurers tools to enhance efficiency. A further section discusses implications for policy.

The paper adds to the literature by applying a uniform set of criteria to enable a systematic comparison of choice and competition in statutory health insurance across the four countries and by providing a comprehensive and up to date cross-national overview of health insurance coverage, regulation and market structure. Because a comparison of four countries cannot hope to explore the complexities of reform implementation in great depth, detailed analysis of the policy context in each country is beyond the scope of the paper. An evaluation of the outcomes of insurer competition is also beyond the paper's scope; robust evaluation poses challenges due to lack of data, noise from other reforms and absence of knowledge about the counterfactual, and comparative evaluation is further complicated by cross-national differences in goals and implementation. Finally, the paper does not aim to test the validity of the three conditions (that is, the extent to which they are necessary for insurer competition to 'work'); rather, it uses the conditions to structure discussion about differences across countries and to highlight areas requiring policy attention.

\section{Policy history, development and goals}

This section outlines the history and development of policies to facilitate insurer choice and competition in the four countries in chronological order. It reviews the policy goals underpinning more recent reforms. Awareness of the goals specific to each country, and the context in which they have been formulated, is important for the analysis of implementation and discussion of policy implications in subsequent sections. Table 1 , Table 2 and Table 3 depict key features of current health insurance coverage, regulation and market structure.

Tables 1-3 here

\section{Switzerland}

Choice of health insurer in Switzerland dates to 1911, when the first federal law on Sickness and Accident Insurance came into force. At that time the health insurance system was mainly managed by small-scale, private, non-profit institutions. State subsidies were required to encourage people to enrol from an early age and to make 
premiums more affordable. In order to qualify for subsidies, insurers had to offer open enrolment to people under the age of 55 and portable benefits. They also had to limit the difference between premiums for men and women to 25\%. By 1945, about half of the population was covered, expanding to near-universal coverage between 1985 and 1990.

Under the 1911 legislation, switching was not easy or costless for everyone. Weak regulation, premiums based on age at enrolment, and the entry of new insurers led to a degree of unfair competition based on risk selection. During the early 1990s, many sickness funds collapsed or merged with others to avoid bankruptcy. Concerns about unequal access to health insurance, combined with concerns about solidarity, rising health expenditure and gaps in coverage, gave rise to a new Federal Health Insurance Act (FHIA) in 1996. To address access concerns and to encourage fair competition based on price and quality, the new law made health insurance universally compulsory, extended open enrolment and introduced a standard benefits package, risk equalisation and minimum user charges. The law maintained collective contracting of providers, but to enhance efficiency by encouraging better purchasing, it gave insurers leeway to develop and sell so-called managed-care plans to those willing to accept limited choice of provider in return for lower premiums. Managed-care plans can involve referral to specialists, selective contracting and capitation-based provider payment. The Swiss reform therefore aimed to enhance equity of access to health care, to strengthen solidarity and, at the same time, to create incentives for organizational innovation and expenditure control (11).

\section{Belgium}

Compulsory health insurance for employees was established in Belgium in 1944 and is currently managed by five non-governmental, non-profit sickness fund associations comprising 54 local sickness funds, a special fund for railroad employees and a public insurer of last resort (12). In 1964 the government extended compulsory coverage of inpatient care to self-employed people and in 2008 coverage for the self-employed was further extended to include outpatient care.

Although Belgian residents have enjoyed free choice of sickness fund since 1944, this choice has not been regarded as a means of stimulating insurer competition. Rather, funds were associated with different political or religious groups and choice simply allowed people to express their preference for a 'Christian' or 'Socialist' insurer. In 1995 the government introduced partial prospective funding of sickness funds, accompanied by risk equalisation, to make them take on some financial risk. Even so, the underlying policy intention was not to foster competition among sickness funds but to place them on an equal footing and encourage them to contain health care costs (13). The sickness funds were not given new tools, such as selective contracting, with which to influence health service quality and costs (14).

Belgium is the only one of the four countries to have a public insurer of last resort. Unlike the sickness funds, the public fund has no historical affiliation to political or religious groups, nor does it offer compulsory additional benefits ${ }^{2}$ (as the local sickness

\footnotetext{
${ }^{2}$ Compulsory additional benefits refer to items not included in the statutory benefits package, which does not vary across insurers. Additional benefits are offered at the discretion of individual insurers (and might include things like orthodontics, alternative medicine or home care services); they must be
} 
funds do). As a result, its small share of the market (1\%) is made up of people who do not wish to pay for additional benefits or who prefer a 'neutral' fund.

\section{The Netherlands}

In 1991 the Dutch government introduced free choice of non-profit sickness fund for the two-thirds of the population eligible for statutory health care coverage and sickness funds began to take on financial risk for their enrolees' health care costs. Free choice of fund was intended to improve efficiency and responsiveness to consumer preferences. By the end of 2005, the sickness funds bore financial risk for 53\% of their revenue. However, there was growing dissatisfaction among policy makers with the absence of other incentives for efficiency and innovation within the prevailing regulatory framework, coupled with concerns about long waiting times for specialist care. The increasingly heavy regulation required to ensure access to voluntary health insurance (VHI) for the third of the population excluded from statutory health care coverage ${ }^{3}$ was also seen as unsatisfactory.

The 2006 Health Insurance Act extended statutory coverage to the whole population under a new system managed by private insurers (some of whom were formerly sickness funds; others had been active in the market for VHI). Insurers now have stronger incentives to be prudent purchasers of health services, including increased financial risk (92\% of revenue) and some tools to stimulate competition among providers. It was expected that over time consumer choice of insurer would reduce the emphasis on government regulation of health care supply and increase the use of strategic purchasing to enhance efficiency. This in turn would make health care more affordable, more responsive to patient needs and more effective, bringing about a better balance between costs and benefits (8).

\section{Germany}

Historically, statutory health insurance (SHI) in Germany was compulsory for all bluecollar employees and for white-collar employees with earnings below a threshold. Employees were assigned to a non-profit, quasi-public sickness fund based on geographical or occupational criteria. Only white-collar employees with earnings above the threshold were allowed to choose between voluntary enrolment in the SHI system, buying substitutive VHI from private insurers or not being covered at all. If they chose SHI, they had free choice of sickness fund and the option of switching fund at regular intervals (unlike other employees) (15). Assigned membership among blue-collar and lower-earning white collar employees led to large variation in income-related contribution rates - of up to 8 percentage points in the early 1990s - because sickness funds covered people with very different income levels and risk profiles (16). Over time, variation in contribution rates and differences in the rights of white- and blue-

\footnotetext{
purchased by all those who enroll with a particular insurer. The local sickness funds have traditionally offered a mixture of compulsory additional benefits and voluntary supplementary and complementary health insurance. In 2010 a change in the law separated compulsory and voluntary activity. From 2012 voluntary additional benefits have been sold by new non-profit societies of mutual assistance, which are part of the national sickness fund associations.

${ }^{3}$ Before 2006, people with incomes above a certain level, and their dependants - around one third of the population in total - were not eligible for statutory coverage of health care costs. These individuals relied on voluntary health insurance sold by competing private insurers.
} 
collar employees came to be regarded as inequitable, particularly since blue-collar employees often experienced higher contribution rates than white-collar employees.

In 1992 the German legislature extended free choice of sickness fund to almost all those covered by SHI, with effect from 1996. This was primarily intended to tackle equity concerns about varying contribution rates by permitting anyone to choose a sickness fund with a lower contribution rate. It was expected that free choice would lead to a convergence in contribution rates. Since the national and international ideological climate at that time favoured the introduction of market mechanisms in health care, it was also hoped that fostering competition within the SHI system would control health care costs and increase efficiency. Free choice of sickness fund was preceded by the introduction (in 1994-1995) of risk equalisation to prevent risk selection and ensure contribution rates would signal a sickness fund's ability to operate efficiently. It was clear from its inception that the risk-adjustment formula was crude, but the government did not have the tools and data necessary to implement a more sophisticated scheme. Because the sickness funds bore significant financial risk, any risk adjustment was seen as better than none.

The change in legislation made health insurance compulsory for all permanent residents in 2009. SHI covers employees (with the exception of civil servants) and their dependants (non-earning spouses and children), the unemployed, pensioners, students, farmers and (since 2007) anyone not covered by substitutive VHI. Employees whose gross wages exceed $€ 50,850$ a year (in 2012) - less than $15 \%$ of the population - can choose between statutory and private cover, but they must have some form of insurance. Less than a third of this high-earning group opts for private cover. SHI covers about $85 \%$ of the population, private VHI covers around $10 \%$ (more than half of whom are civil servants and the self-employed) and government schemes cover about $4 \%$.

\section{Consumer mobility}

For insurers, the threat of exit may be muted if people cannot move (switch) freely from one insurer to another, undermining a major pre-requisite for insurer competition. In the absence of a single metric to establish the degree of consumer mobility in insurance markets (there is no optimal rate of switching), a range of factors needs to be considered. These include financial and administrative barriers to joining a new insurer, the reasons people give for switching or staying put and the characteristics of those who do and do not switch. If non-switchers are mainly people with predictably high health care costs - a situation termed 'adverse retention' (17) - the instrumental effect of exit might be severely weakened or even eliminated, particularly if risk adjustment (see below) is absent or of poor quality. Insurers who assume that these enrolees have no real alternative may not have much incentive to respond to their preferences (18) and might attempt to erode service quality or encourage them to switch.

\section{Strategies to facilitate switching}

All four countries employ multiple strategies to ensure that the whole population is able to switch from one insurer to another, for statutory benefits, with relative ease and at 
low cost: open enrolment, ${ }^{4}$ coverage of pre-existing conditions, premiums that are not linked to individual risk of ill health, fully portable benefits, a standardised benefits package to enable straightforward price comparisons, good comparative information available through newspapers, web sites ${ }^{5}$ and intermediaries, and risk adjustment to compensate insurers for covering high-risk individuals. These universally applied strategies mean that the financial and administrative costs of switching are likely to be low. Other transaction costs may be high, however, as we discuss below.

\section{Switcher characteristics}

Switching rates vary across the four countries, with the lowest rates in Belgium and the highest rates in Switzerland (Table 4). People who switch are more likely to be younger in Germany, the Netherlands and Switzerland (no data are available for Belgium) and are more likely to be healthier in Germany and the Netherlands. In Switzerland people who switch are more likely to be healthier if they have VHI (reporting their health to be 'very good' rather than 'good' or 'poor').

Table 4 here

\section{Reasons for switching and for staying put}

Reasons for switching differ in importance across the four countries, with price playing no role in Belgium and a significant role in the Netherlands, Switzerland and Germany. Consumer perceptions of differences in quality seem to play some role in all four countries (Table 5). The Netherlands and Switzerland have the largest differences in price across insurers. In the Netherlands the gap between the cheapest and most expensive community-rated premiums is not as large as in Switzerland and has narrowed since 2006, while the average community-rated premium remains below the break-even threshold calculated by the Ministry of Health in 2006 (8).

Table 5 here

In contrast, premiums have grown rapidly in Switzerland in recent years, prompting the much higher than usual rates of switching seen in 2008/2009 and 2009/2010 (Table 4), and premium variation is substantial. By selecting the highest deductible and enrolling in a managed-care network, policy holders in Switzerland can lower their premiums by up to $50 \%$; in Zurich canton, for example, $5 \%$ of people paid an annual premium of less than CHF 3,500 (€2,895) in 2010, while 5\% paid over CHF 4,900 (€4,053), a difference of more than CHF $1,400(€ 1,158)(19)$. Unlike the Netherlands, there is no evidence of premium variation within cantons narrowing over time (20), which may be an indication of insufficient consumer mobility.

In Germany in 2010 only 13 of the (then) more than 150 sickness funds charged additional community-rated premiums and these are low in comparison to the Netherlands and Switzerland. Nevertheless, people appear to be very sensitive to price. In the first half of 2010 sickness funds that introduced an additional community-rated premium of $€ 8$ per month in February of that year lost up to $20 \%$ of their enrolees (21).

\footnotetext{
${ }^{4}$ In Belgium since 2007 only, replacing a system of guaranteed renewal of contract.

${ }^{5}$ Government-sponsored web sites in the Netherlands (www.kiesbeter.nl) and (since 2012) in Switzerland (www.priminfo.ch) and private initiatives in all four countries.
} 
In 2011 the cap on additional premiums was lifted, which may intensify price competition in future.

Survey data from the Netherlands and Switzerland suggest many people feel no need to switch because they are satisfied with their current insurer (45\% in the Netherlands and $79 \%$ in Switzerland) $(22,23)$. There is also evidence of people preferring to maintain the status quo (24) or using subjective measures of quality to determine insurer choice. Forty per cent of people surveyed in Switzerland chose an insurer based on parents' and friends' choices and 'tradition', while $13.5 \%$ said they stayed with their insurer out of habit; those who had been with an insurer for longer were less likely to express an intention to switch (23). About 25\% said they did not try to choose the insurer with the lowest premiums. Prior to the 2006 reform in the Netherlands, the most frequently mentioned reason for being enrolled with a particular insurer was having joined the fund in early adulthood (25), a status quo bias that was perhaps reinforced by the relatively small difference between insurers at that time. In spite of the growth in premium and product differentiation since then, the proportion of Dutch respondents who believe they do not stand to benefit much by switching has risen from $68 \%$ in 2006 to $74 \%$ in 2008 and $18 \%$ said it was too much trouble to switch (22). In 2009 7\% said they did not switch because they felt they would not be able to obtain a new VHI policy if they changed to a new insurer for statutory cover, up from 4\% in 2006 (26).

\section{Barriers to consumer mobility}

Research indicates that many people in the four countries have legitimate reasons (from a policy perspective) for not switching. However, the links between age, health and switching in Germany and the Netherlands, and between age, health, VHI and switching in Switzerland suggest that older and less healthy people may face barriers to switching. In the following paragraphs we discuss three reasons why this might be the case.

First, evidence from research in the United States shows that switching costs tend to be higher for older and less healthy people (27), who risk having to change provider, having to interrupt current treatment and losing valuable knowledge about how things work with their current insurer $(27,28)$. In general, switching costs are probably much lower in the European countries than in the United States, although they are far from absent, as the $18 \%$ of Dutch people reporting it was too much trouble to switch demonstrates (22). However, if selective contracting becomes more common in these European health systems (see below), the costs of switching could grow. Selective contracting is intended to enhance productive efficiency, but it has the potential to undermine continuity of care and equity of access to services (29).

Second, the availability of complementary or supplementary VHI may reduce consumer mobility among older and less healthy people if sales of voluntary and statutory cover are linked, creating a lock-in effect $(30,31)$. In Belgium, the Netherlands and Switzerland VHI is sold by entities belonging to the same sickness funds that provide statutory cover (Table 3). Until recently, Belgian households were required to purchase voluntary and statutory cover from the same entity and VHI was the main way in which insurers differentiated themselves. Legislation in Switzerland explicitly prevents insurers from linking the sale of voluntary and statutory cover (20, 26), but there are close ties between them; 93\% of those with voluntary policies (purchased by $75 \%$ of the population) obtain both types of cover from the same insurer, 
partly because reimbursement is much simpler when it comes from one company (20). In the Netherlands VHI covers about $90 \%$ of the population and most people buy voluntary and statutory cover from the same insurer (8). Although the termination of voluntary contracts when enrolees switch to another insurer for statutory cover is prohibited by law, insurers frequently breach the law $(26)^{6}$. Dutch insurers can raise VHI premiums when people switch for statutory cover (and many do) and there are other ways in which they can link the sale of voluntary and statutory cover ${ }^{7}$. In 2009 $97 \%$ of insurers adopted at least one linking strategy, a much higher proportion than in 2006 (at least $44 \%$ of insurers) (26).

There is no clear evidence of insurers using VHI to select risks in the statutory market in any of the four countries $(20,26,31)$. Nevertheless, consumer beliefs about risk selection by insurers in the VHI market seem to be a powerful barrier to switching in the statutory market for less healthy people. In Switzerland switching was found to be less likely among people with VHI whose self-reported health was less than 'very good'. In the Netherlands the proportion of non-switching survey respondents who said they did not switch because they believed they would not be able to obtain a new voluntary policy at all due to their age or health status (that is, they believed insurers would reject their application for voluntary cover) rose from 4\% in 2006 to 7\% in 2009 (26). The proportion of respondents who gave this as the most important reason for not switching rose from $1.5 \%$ in 2006 to $3.4 \%$ in 2009. Similar figures applied to respondents who did not switch but seriously considered doing so.

Third, choice 'overload' may reduce consumer mobility by lowering transparency, which increases the transaction costs of switching (32,33). Swiss research shows how the probability of switching is significantly lower in areas with larger numbers of insurers, even where premium variation is significant (23). Furthermore, among survey respondents who were very dissatisfied with their current insurer, 34\% intended to switch in areas with fewer than 50 statutory health insurers versus $22 \%$ in areas with more than 50 insurers. Growing product differentiation can also contribute to choice overload. With the exception of Belgium, insurers have many more ways now than in the past of modifying the standard statutory product: they can offer choice of cash or in-kind benefits, higher deductibles in return for lower premiums or contributions, noclaims bonuses and reduced user charges for accepting gatekeeping, disease management or use of preferred providers (Table 6). These options may benefit some individuals but there is likely to be a trade-off in terms of transparency and ease of price comparison $(34,35)$. They may also restrict choice in other areas. In Germany people who opt for a contract involving gatekeeping, integrated care or cost reimbursement lose the right to switch for a three-year period. In Switzerland parliament had proposed to offer people choosing managed care the option of a three year contract (instead of an annual one), but the proposal was rejected in a referendum held in 2012.

\footnotetext{
${ }^{6}$ Recent research found that, when queried, the customer services representatives of half of all insurers in the Netherlands specified that a voluntary contract would be terminated if the enrolee switched to another insurer for statutory cover (26).

${ }^{7}$ Only offering voluntary contracts in combination with statutory cover; charging higher premiums when people apply for voluntary cover alone; applying more stringent acceptance criteria when people want only voluntary cover; and offering free voluntary cover for children if parents and children obtain statutory cover from the same insurer (26).
} 
Table 6 here

\section{Incentives for risk selection}

Insurer competition should be based on price and quality rather than on risk selection (encouraging enrolment among people with lower-than-average risk and discouraging or deterring enrolment among those with higher-than-average risk). If insurers are able to generate a surplus (at least in the short term) through risk selection, they may not be sufficiently motivated to focus on operating efficiently - that is, obtaining most output from least input. Risk selection is also undesirable because it may threaten equitable, affordable access to health insurance and quality of care (7). Incentives to select risks will be stronger if insurers bear financial risk and if the money they have to spend per enrolee does not reflect the enrolee's risk of ill health (36). The degree of risk selection that takes place in a given situation may also depend on the extent to which insurers have access to selective tools - for example, the ability to link the sale of statutory and voluntary health insurance. The primary mechanism for reducing incentives to select risks is risk adjustment (also known as risk equalisation).

\section{Financial risk}

Prior to the introduction of insurer competition, insurers in Belgium and the Netherlands did not bear any financial risk. They were little more than financial conduits, channelling centrally raised resources to providers or raising their own revenue but with leeway to increase contribution rates and accumulate deficits. The degree of financial risk borne by insurers has increased in all four countries and is particularly high in Germany, Switzerland and the Netherlands, but remains low in Belgium. Each country has focused on developing a risk-adjustment formula to allocate resources to health insurers, although there are differences across countries in the design of the formula and in the degree of insurer revenue subject to the formula (Table 7).

Table 7 here

\section{Risk equalisation}

The extent to which risk equalisation succeeds in lowering incentives to select risks largely depends on the sophistication of the formula ${ }^{8}$, but also on the presence of risksharing arrangements such as ex-post compensation based on actual health care costs incurred. Risk sharing lessens the degree of financial risk insurers bear and therefore lowers incentives for risk selection, but it also dampens incentives to operate efficiently (36). All four countries have strengthened their risk equalisation schemes in the last ten years and Belgium, Germany and the Netherlands now have relatively sophisticated formulas that include health-based risk adjusters (37-39).

Incentives for risk selection are low in Belgium because of the low level of financial risk the sickness funds bear: only $30 \%$ of sickness fund revenue is subject to risk adjustment and insurers are only financially responsible for $25 \%$ of any difference

\footnotetext{
${ }^{8}$ The formula need not be perfect, but it must be sufficiently sophisticated to make risk selection more costly to the insurer than it is worth.
} 
between allocated revenue and actual health care expenditure. Risk selection does not seem to be a policy concern, even though the link between statutory and voluntary cover provides insurers with an effective selection tool $(13,14)$. At the same time as the current arrangements limit incentives for risk selection, they are probably not sufficient to motivate insurers to operate more efficiently. Insurers in both Germany and the Netherlands have incentives to select risks beyond the criteria included in the risk adjustment formula. However, German insurers may have less opportunity to do so, since the market for complementary VHI is small in Germany (in terms of population coverage) compared to VHI markets in Belgium and the Netherlands (31).

Insurers in Switzerland probably face the strongest incentives to select risks because they bear full financial risk for outpatient care (although they are much less at risk for inpatient costs, which they share with the cantons) $(40,41)$ and, perhaps more importantly, the Swiss risk equalisation scheme was weak for over 20 years, adjusting for age and gender only. The need for better risk adjustment was recognised in Switzerland for many years, but attempts to improve the formula were blocked or slowed down by lobbying on the part of some insurers who were highly influential politically (41). In 2012 the Swiss formula was substantially improved by the introduction of a new factor, hospitalisation in the previous year; other factors may be introduced in the near future $(42)^{9}$.

\section{The availability and use of tools to enhance efficiency through strategic purchasing}

The final dimension of interest is the extent to which individual insurers are able to influence health care quality and costs - in other words, to engage in strategic purchasing. If insurers were not able to do this, the main reasons for encouraging them to compete with each other would be to ensure that they provided quality customer services, kept administrative costs to a minimum and passed on any cost savings to enrolees in the form of lower premiums. These would be satisfactory outcomes, but the rationale for insurer competition goes beyond notions of customer service and administrative efficiency. At least in theory, it encompasses the notion of enhancing efficiency at the level of the health system through stronger purchasing leading to better delivery of health care.

\section{The range of tools available}

Table 8 and Table 9 show how insurer-provider relations are regulated and the availability and take-up of tools insurers might use to engage in strategic purchasing. The tools range from allowing insurers to integrate with providers, which would strengthen incentives for expenditure control, to permitting them to selectively contract providers, choose how best to reward or penalise good or poor provider performance and influence the types of services to which enrolees have access. The list of tools included in Table 9 is not exhaustive.

Tables 8-9 here

\footnotetext{
${ }^{9}$ Strengthening the risk adjustment formula was the only part of the reform rejected in a 2012 referendum that had the support of a large majority of the population.
} 
In Belgium, Germany and Switzerland collective negotiation between insurers and providers is the default method of setting prices and concluding contracts, which limits the ability of individual insurers to influence the quality and cost of most health services, but preserves free choice of provider for service users (Table 8). In Germany and Switzerland insurers have a degree of leeway in the contracting process. Policies offering a GP gatekeeping model of care allow German sickness funds to selectively contract GPs (in addition to the collective contract) and negotiate prices and other conditions on a bilateral basis. The same applies if providers sign integrated-care contracts with sickness funds. Similarly, Swiss insurers are allowed to engage in selective contracting, negotiate lower prices and use capitation to pay providers when people choose managed-care plans (43). However, because collectively negotiated prices and contracts are the norm in both countries, insurers need to offer particularly attractive terms to convince doctors to sign alternative contracts. Insurers in the Netherlands have more freedom in contracting than their counterparts in the other countries. Since 2006, selective contracting has been permitted for all forms of care and, while the government continues to set maximum prices for GP services and prices for one-third of hospital services, the aim is to move towards greater price liberalisation.

\section{Take up of purchasing tools}

There are clear differences between Belgium and the other countries in the range of tools available to enable strategic purchasing by insurers. The more limited recourse to purchasing tools in Belgium reflects the absence of national policy emphasis on competition as a mechanism for stronger purchasing and a preference for sickness funds to operate collectively. Although this suggests Belgian insurers are at a disadvantage when it comes to purchasing, insurers in the other countries do not make full use of purchasing tools for a range of reasons including legal restrictions, concerns about restricting consumer choice, technical challenges and lack of information.

Legal restrictions preclude widespread take-up of some tools in Germany and Switzerland. German sickness funds can only engage in selective contracting or develop their own clinical guidelines and prescription drug formularies if funds, GP associations and patients opt for gatekeeping contracts or if funds, providers and patients opt for integrated-care contracts. A proposal by the federal government in the early 2000s to extend selective contracting to elective inpatient treatment was blocked by the states on the grounds that it would threaten their ability to plan hospital capacity. For Swiss insurers, many purchasing tools are limited to managed-care plans, primarily to preserve free choice of provider for those who value it. In $201046.9 \%$ of enrolees opted for a managed-care contract (44), but only a few of these chose the capitation model involving selective contracting; most chose a less restrictive family doctor or call centre model (45). Recent legislation passed by the Swiss parliament in 2011 aimed to boost the development of integrated care networks, to strengthen financial incentives to enrol in a capitation-based managed care plan (by increasing user charges for those who do not enrol from 10 to 15 per cent of care costs) and to ban vertical integration of insurers and providers (42), but was rejected in a referendum held in 2012.

A different form of legal restriction occurs when national authorities block the use of permitted tools on the grounds (for example) that they are anti-competitive. In 2009 a dominant regional insurer and a group of local health care providers, including GPs, 
tried to take over a failing Dutch hospital (46). Some members of parliament pressured the Minister of Health to prevent the takeover on the grounds that all parties involved would have a financial incentive to direct patients toward the hospital in question, which would restrict consumer choice. Conversely, residents expressed a desire for their local hospital to remain open since closure would also have limited their options (46). Something similar can be seen in Germany, where ownership of ambulatory care centres by hospitals is disputed. The government had proposed to prohibit this but did not introduce the necessary legislation.

Concerns about restricting consumer choice of provider may prevent insurers from using selective contracting. In Germany and the Netherlands insurers reveal a strong preference for offering enrolees financial incentives (lower user charges or lower premiums) to choose preferred provider networks or GP gatekeeping. It is argued that Dutch insurers are reluctant to de-select hospitals because they believe consumers will regard them as being motivated by financial rather than quality considerations $(46,47)$. Some of these concerns may be justified, since consumers generally reveal a preference for wider choice of provider: the GP gatekeeping option has not been as popular among patients and sickness funds as expected in Germany (partly because evaluations do not show savings); take-up of preferred provider networks in the Netherlands is low; and most Swiss enrolees who opt for managed-care plans do not opt for plans involving selective contracting (45). Selective contracting has also been resisted by regulators and providers. In 2010 a large Dutch insurer published hospital rankings for quality of breast cancer care on its website and announced it would no longer send enrolees with breast cancer to hospitals that did not reach minimum volume thresholds for breast cancer treatment, a move supported by patient groups (48). The Dutch Healthcare Inspectorate initially stated that all breast cancer treatment in the Netherlands met its standards for responsible care, while the Dutch Association of Surgeons suggested the insurer had used inappropriate standards (48). The decision was upheld by the courts, however, and other insurers soon followed suit.

Some purchasing tools present technical challenges under certain circumstances, particularly selective contracting and price negotiation. As a result, insurers may lack the capacity to use them effectively or the transaction costs involved may be high. In Germany, selective contracting is unattractive partly due to the complexity of having to re-calculate global payments to office-based physicians (Table 8) when some patients are treated under separate contracts, and partly because hospitals cannot be de-selected on a service-by-service basis (as in the Netherlands). Switzerland has seen mergers among private clinics to strengthen provider bargaining power and increase their ability to negotiate higher prices with insurers. Since 2006, price negotiation has been promoted as a key purchasing tool in the Netherlands, where individual insurers are encouraged to negotiate prices with individual hospitals for pre-defined services covering 4,000 Diagnostic Treatment Combinations (DTCs, case-based payments per episode of illness) equal to $70 \%$ of hospital revenue (up from one third of hospital revenue in 2010). To help insurers cope with the magnitude of the task, the Dutch Insurers' Association publishes an annual purchasing guide focusing on 200 of the most frequently used DTCs (49).

The lack of information on health care quality and costs, particularly at the level of individual providers, is a major obstacle to the effective use of some purchasing tools, notably selective contracting, price negotiation and performance-based provider 
payment. Without good information it is not possible to carry out systematic benchmarking, which in turn precludes fully informed decision making by insurers and enrolees. There is some public disclosure of information about provider performance (mainly hospitals) in all four countries and government-led efforts to improve data collection and disclosure in Germany (50) and the Netherlands (8). However, public disclosure is sometimes controversial (as in the Dutch case) and the lack of informative indicators based on reliable data may represent a significant barrier to improved purchasing for some time to come.

\section{Policy implications}

This paper has reviewed the policy goals underlying the introduction of insurer choice and competition for statutory health benefits in Belgium, Germany, the Netherlands and Switzerland. It has examined policy implementation in three areas: consumer mobility, incentives for risk selection, and the availability and use of tools to enhance efficiency. In this section we discuss important similarities and differences across the four countries, consider the extent to which the conditions underpinning the theoretical rationale for insurer competition - to enhance allocative and productive efficiency, mainly through stronger purchasing - have been met in practice, and highlight some implications for policy.

The range of policy goals underlying insurer choice and competition varies across the four countries, but there is common ground. Germany and Switzerland introduced reforms primarily to address access and equity concerns. Belgium is the only one of the four countries in which public policy has not emphasised competition among insurers. It was included in the analysis because the shifting of some financial risk to sickness funds in 1995 aimed to stimulate greater expenditure control; after 1995, consumer choice of insurer became an integral part of the incentive structure facing sickness funds, even though it was not originally intended to have that effect. Expenditure control has also been one of the goals of insurer competition in Germany and Switzerland. Germany and the Netherlands expected consumer choice of insurer, combined with greater financial risk for insurers, to enhance efficiency and quality in health care administration and delivery. Efficiency was not explicitly stated as a goal in Switzerland, but it has been used in public debate to justify maintaining the status quo in other words, alternatives to insurer competition are portrayed as being likely to lower efficiency.

Risk adjustment has been a priority for policy makers - for good reason, since risk selection erodes insurers' incentives to operate efficiently and may threaten equity and quality of care. However, while all four countries have introduced and improved risk adjustment formulas, there is variation across countries in the quality of the formula and in the pace at which it has been strengthened. Policy makers in Germany accepted that their original formula was relatively crude because they lacked the necessary information for a more effective formula; once they had the information, however, they were able to refine the formula. The weakness of Switzerland's formula was widely acknowledged nationally, but action to strengthen it was blocked for many years by industry lobbying rather than by lack of data. In spite of the energy devoted to strengthening formulas, no country has fully eliminated incentives to select risks (38). Circumstantial evidence for all of the countries indicates there is risk selection through targeted advertising, through the use of reminders and discounts and through product 
differentiation in $\mathrm{VHI}^{10}(8,20,38,51)$, while anecdotal evidence suggests insurers in some countries have tried to deter high risks from enrolling ${ }^{11}$. Further strengthening of the formula continues to be a priority for Switzerland, but there is scope for improvement in the other countries too.

Consumer mobility has not received as much attention as risk adjustment. Extensive regulation to facilitate mobility (much of it predating the introduction of insurer competition) may mean that switching costs are negligible for most people in all four countries. However, a small but growing body of evidence suggests consumer mobility is limited among older and less healthy individuals - those likely to use health services on a regular basis. This ought to be a cause for concern, because if insurers feel these enrolees are unlikely to switch, they may not have sufficient incentive to provide them with high-quality care.

Research identifies two potential barriers to consumer mobility: first, increasingly close links between the sale of statutory health insurance and complementary or supplementary VHI and second, choice overload. Tied sales of statutory and voluntary health insurance are prohibited in the Netherlands and Switzerland, but insurers have found ways of linking the two types of cover. While a mixture of regulation, risk adjustment and accepted norms seems to have prevented most insurers from using VHI to select risks for statutory health insurance, it has not allayed consumer fears about obtaining adequate voluntary cover when switching to a new insurer for statutory cover. This is a particular problem in the Netherlands and Switzerland, where VHI coverage is widespread. The Belgian solution - greater regulation of $\mathrm{VHI}^{12}$ - may not be attractive to policy makers elsewhere, in part due to concerns about infringing EU internal market rules (52). Nevertheless, the importance of VHI as an obstacle to consumer mobility among older and less healthy people requires some form of policy action. Better risk adjustment might help, alongside better information for consumers and closer scrutiny of the sales process. Policy attention should also focus on the potential for choice overload, particularly in the context of a trend towards allowing insurers to offer differentiated benefits to suit individual preferences - for example, different levels of user charges or additional services. It is well established that product differentiation, even at the margin, lowers transparency (35). This in turn increases transaction costs for consumers and can therefore undermine competition.

Making sure insurers have and use tools to influence health care quality and costs is essential if competition is to enhance efficiency through stronger purchasing. Individual insurers in Belgium do not have these tools, insurers in Germany and Switzerland have access to some tools, and insurers in the Netherlands have access to a wider range of

\footnotetext{
${ }^{10}$ Swiss insurers use holding companies to direct enrolees to a plan with an 'appropriate' premium, while in the Netherlands the growth of group contracts has allowed insurers to offer discounts to some groups (employers, self-employed people, sports clubs) but not others (patient associations) (33).

${ }^{11}$ In 2011 several hundred members of an insolvent sickness fund in Germany were put off joining other sickness funds through statements such as "we cannot guarantee that your insurance card will be ready in time" etc; the Federal Insurance Authority had to intervene and reminded the sickness funds to obey legal requirements.

${ }^{12}$ In Belgium open enrolment is guaranteed for compulsory additional benefits. In 2007 legislation extended open enrolment requirements to the sale of VHI and prohibited premium differentiation based on pre-existing medical conditions (except for people aged 65 years and above who did not already hold a similar policy with their former insurer).
} 
tools but do not always use them. Differences in policy goals across countries - the lack of policy emphasis on competition in Belgium and the policy emphasis on access and equity goals in Germany and Switzerland - may explain some of this variation; but the experience of the four countries under review suggests that differences may arise for other reasons, including lack of relevant data and stakeholder resistance to the use of some tools.

In all four countries commentators have emphasised the need for better information about health care quality and costs. The importance of good information cannot be overstated, particularly in facilitating selective contracting, setting appropriate prices, developing priorities, fostering best practice and linking provider payment to performance. However, good information is not the only pre-requisite for strategic purchasing. Policy also needs to ensure that insurers have incentives to operate efficiently, that there is sufficient capacity to make use of tools, and that incentives are aligned across the health system.

Resistance seems inevitable given that some purchasing tools have the potential to restrict enrolee choice (of both insurer and provider, in the case of selective contracting), many of them will affect provider autonomy and income, and most require information that is not readily available. Cross-country variation may therefore reflect differences in the extent to which policy makers and insurers are willing and able to curb enrolee choice and challenge providers. This in turn may reflect uncertainty on the part of policy makers about the appropriate place for competition among insurers or among providers? - and about who is best placed to influence provider behaviour - government, insurers collectively, individual insurers or health care users?

\section{Conclusions}

Reforms introducing insurer choice and competition have had diverse goals in European health systems. They have not always aimed to enhance efficiency, but where they have, expectations about efficiency gains may conflict with other stated goals such as expenditure control. Reforms have also been implemented in different ways and in different timeframes. Differences in policy goals explain some but not all of the differences in policy design and development across countries. Not surprisingly, political factors have an explanatory role.

Each country has put in place some measures to meet the three conditions highlighted in this paper as being necessary for insurer competition to enhance efficiency, including extensive regulation to secure consumer mobility, reduce incentives for risk selection and provide insurers with tools for strategic purchasing. However, there are important variations in the implementation of these measures. The pace with which risk adjustment has been strengthened has been much slower in Switzerland than in the other countries and, in spite of significant investment in risk adjustment, incentives for risk selection remain in all four countries. Consumer mobility is not equally distributed across the population in three out of the four countries for which data are available. Better risk adjustment may enhance mobility among older and less healthy people, but policy makers need to pay more attention to the way in which insurers link the sale of statutory and voluntary health insurance, particularly in the Netherlands and Switzerland. In Belgium, Germany and Switzerland collective negotiation between 
insurers and providers curbs the ability of individual insurers to influence the quality and costs of many health services. Insurers in the Netherlands have good access to efficiency-enhancing tools; nevertheless, data and capacity constraints and resistance from enrolees, providers, regulators and politicians limit the extent to which tools are used.

The experience of the four countries reviewed in this paper offers an important lesson to countries thinking of introducing competition in statutory health insurance: it is not straightforward to put in place the conditions under which health insurance competition can enhance efficiency. Policy makers should not, therefore, underestimate the challenges involved. Effective risk adjustment requires extensive data and may be obstructed by insurers. Consumer mobility rests on substantial regulation and may be threatened where the same insurers sell statutory and voluntary benefits, the take up of VHI is significant and there is reluctance to regulate the VHI market. Finally, the availability and use of tools to enhance efficiency may be opposed by a range of stakeholders. 


\section{References}

1. Thomson S, Foubister T, Mossialos E. Financing health care in the European Union: challenges and policy responses. Copenhagen: World Health Organization on behalf of the European Observatory on Health Systems and Policies, 2009.

2. Schneider P. Health insurance and competition. Washington DC: The World Bank, 2009.

3. Thomson S, Võrk A, Habicht T, Rooväli L, Evetovits T, Habicht J. Responding to the challenge of financial sustainability in Estonia's health system, report prepared for the Ministry of Social Affairs in collaboration with the Estonian Health Insurance Fund and the World Health Organization. Copenhagen: World Health Organization Regional Office for Europe, 2010.

4. Bevan G, van de Ven WPMM. Choice of providers and mutual healthcare purchasers: can the English National Health Service learn from the Dutch reforms? Health Economics, Policy and Law. 2010;5(Special Issue 03):343-63.

5. Enthoven AC. Managed competition: an agenda for action. Health Affairs. 1988;7(3):25-47.

6. Figueras J, Robinson R, Jakubowski E, editors. Purchasing to improve health systems performance. Buckingham: Open University Press; 2005.

7. van de Ven WPMM, Ellis RP. Risk adjustment in competitive health plan markets. In: Newhouse JP, Culyer AJ, editors. Handbook of health economics. Amsterdam: Elsevier; 1999. p. 755-845.

8. Westert GP, van den Berg M, Zwakhals SLN, de Jong JD, Verkleij H, editors. Dutch health care performance report 2010. Bilthoven: RIVM (National Institute for Public Health and the Environment); 2010.

9. Schut E, van de Ven WPMM. Effects of purchaser competition in the Dutch health system: is the glass half full or half empty? Health Economics, Policy and Law. 2011;6(1):109-23.

10. Hendriks M, Spreeuwenberg P, Rademakers J, Delnoij D. Dutch healthcare reform: did it result in performance improvement of health plans? A comparison of consumer experiences over time. BMC Health Services Research. 2009; 9(167). Available from: http://www.biomedcentral.com/1472-6963/9/167.

11. Crivelli L. Consumer-driven health insurance in Switzerland, where politics is governed by federalism and direct democracy In: Thomson S, Mossialos E, editors. Private health insurance and medical savings accounts: history, politics, performance. Cambridge: Cambridge University Press; 2013 in press.

12. Gerkens S, Merkur S. Belgium: health system review. Health Systems in Transition. 2010;12(5):1-266.

13. Schokkaert E, Van de Voorde C. Risk adjustment and the fear of markets: the case of Belgium. Health Care Management Science. 2000;3:121-30.

14. Schokkaert E, Van de Voorde C. Belgium: risk adjustment and financial responsibility in a centralised system. Health Policy. 2003;65(1):5-19.

15. Busse R, Bluemel M, Ognyanova D. Germany: health system review. Health Systems in Transition. 2013 in press.

16. Gaskins M, Busse R. Morbidity-based risk adjustment in Germany - long in coming, but worth the wait? Eurohealth 2009;15(3):28-32.

17. Altman D, Cutler DM, Zeckhauser RJ. Adverse selection and adverse retention. American Economic Review. 1998;88(2):122-6. 
18. Strombom BA, Buchmueller TC, Feldstein PJ. Switching costs, price sensitivity and health plan choice. J Health Econ. 2002;21(1):89-116.

19. Federal Office of Public Health. Statistik der obligatorischen Krankenversicherung 2008. Bern: Federal Office of Public Health, 2008.

20. Dormont B, Geoffard P-Y, Lamiraud K. The influence of supplementary health insurance on switching behaviour: evidence from Swiss data. Health Economics. 2009;18(11):1339-56.

21. Mihm A. Versicherte fliehen vor Zusatzbeiträgen. FAZ.net, 27.7.2010 http://www.faz.net/s/Rub0E9EEF84AC1E4A389A8DC6C23161FE44/Doc E3DD 42423BB964609BD540E7D977D5ED3 ATpl Ecommon Scontent.html. 2010 [cited 1 October 2012].

22. Vos L, De Jong JD. Percentage overstappers van zorgverzekeraar 3\%. Ouderen wisselen nauwelijks van zorgverzekeraar. Utrecht: NIVEL, 2009.

23. Frank R, Lamiraud K. Choice, price competition and complexity in markets for health insurance. Journal of Economic Behavior \& Organization. 2009;71(2):55062.

24. Samuelson W, Zeckhauser R. Status quo bias in decision making. Journal of Risk and Uncertainty. 1988;1(1):7-59.

25. Gresz S, Groenewegen P, Kerssens J, Braun B, Wasem J. Free choice of sickness fund in regulated competition: evidence from Germany and the Netherlands. Health Policy. 2002;60(3):235-54.

26. Roos A-F, Schut FT. Spillover effects of supplementary on basic health insurance: evidence from the Netherlands. European Journal of Health Economics. 2012;13(1):52-61.

27. Buchmueller TC, Feldstein PJ. The effect of price on switching among health plans. J Health Econ. 1997;16(2):231-47.

28. Knaus T, Nuscheler R. Risk selection in the German public health insurance system. Health Economics. 2005;14(12):1253-71.

29. Mobley LR. Effects of selective contracting on hospital efficiency, costs and accessibility. Health Economics. 1998;7(3):247-61.

30. Mossialos E, Thomson S. Voluntary health insurance in the European Union: report prepared for the Directorate General for Employment and Social Affairs of the European Commission. London: London School of Economics and Political Science, 2002.

31. Paolucci F, Schut E, Beck K, Greß S, Van de Voorde C, Zmora I. Supplementary health insurance as a tool for risk selection in mandatory basic health insurance markets: a five country comparison. Health Economics, Policy and Law. 2007;2(2):173-92.

32. Schwartz B. The tyranny of choice. Scientific American. 2004;290(4):70-5.

33. Rice T. Should consumer choice be encouraged in health care? In: Davis JB, editor. The social economics of health care. London: Routledge; 2001.

34. Office of Fair Trading. Health insurance: a report by the Office of Fair Trading. London: Office of Fair Trading; 1996 [cited 20 July 2011]; Available from: http://www.oft.gov.uk/shared_oft/reports/financial_products/oft168.pdf.

35. Office of Fair Trading. Consumer detriment under conditions of imperfect information. London: Office of Fair Trading; 1997 [cited 20 July 2011]; Available from: http://www.oft.gov.uk/shared_oft/reports/consumer_protection/oft194.pdf.

36. van de Ven WPMM. Risk adjustment and risk equalization: what needs to be done? Health Economics, Policy and Law. 2011;6(1):147-56. 
37. van de Ven WP, Beck K, Buchner F, Chernichovsky D, Gardiol L, Holly A, et al. Risk adjustment and risk selection on the sickness fund insurance market in five European countries. Health Policy. 2003;65(1):75-98.

38. van de Ven WPMM, Beck K, Van de Voorde C, Wasem J, Zmora I. Risk adjustment and risk selection in Europe: six years later. Health Policy. 2007;83(23):162-79.

39. Buchner F, Goepffarth D, Wasem J. The new risk adjustment formula in Germany: implementation and first experiences. Health Policy. 2013;109(3).

40. Minder A, Schoenholzer H, Amiet M. Health care systems in transition: Switzerland. Copenhagen: European Observatory on Health Care Systems; 2000.

41. Trottmann M. Reforming health insurance in a direct democracy - lags, inconsistencies, and some important steps forward. Paper presented at the European Conference on Health Economics, Zurich, 18-21 July 2012. 2012.

42. Federal Authorities of the Swiss Confederation. Bundesgesetz über die Krankenversicherung (Managed Care) Änderung vom 30 September 2011 [cited 7 September 2012]. Available from: http://www.admin.ch/ch/d/ff/2011/7441.pdf.

43. Lehmann HJ, Zweifel P. Innovation and risk selection in regulated social health insurance. Journal of Health Economics. 2004;23(12):997-1012.

44. Federal Office of Public Health. Statistik der obligatorischen Krankenversicherung 2010 (Table 11.07d). 2012 [cited 7 September 2012]. Available from: http://www.bag.admin.ch/themen/krankenversicherung/01156/index.html?lang=de.

45. Reich O, Rapold R, Thöni M. An empirical investigation of the efficiency effects of integrated care models in Switzerland. International Journal of Integrated Care 2012;12(January-March) [cited 7 September 2012]. Available from: http://www.ijic.org/index.php/ijic/article/view/685.

46. Maarse H, Paulus A. The politics of health care reform in the Netherlands since 2006. Health Economics, Policy and Law. 2011;6(1):125-34.

47. Boonen LHHM, Schut FT. Preferred providers and the credible commitment problem in health insurance: first experiences with the implementation of managed competition in the Dutch health care system. Health Economics, Policy and Law. 2011;6(2):219-35.

48. Sheldon T. Dutch health insurer ranks hospitals on breast cancer surgery. BMJ. 2010;341(6853):doi: 10.1136/bmj.c6853.

49. Bal R, Zuiderent-Jerak T. The practice of markets in Dutch health care: are we drinking from the same glass? Health Economics, Policy and Law. 2011;6(1):13945.

50. Busse R, Nimptsch U, Mansky T. Measuring, monitoring, and managing quality in Germany's hospitals. Health Affairs. 2009;28(2):w294-w304.

51. Nuscheler R, Knaus T. Risk selection in the German public health insurance system. Health Economics. 2005;14(12):1253-71.

52. Thomson S, Mossialos E. Private health insurance and the internal market. In: Mossialos E, Permanand G, Baeten R, Hervey T, editors. Health systems governance in Europe: the role of EU law and policy. Cambridge: Cambridge University Press; 2010. p. 419-60.

53. Ministerie van Volksgezondheid WeS. VWS-Verzekerdenmonitor 2012. Den Haag: Ministerie van Volksgezondheid, Welzijn en Sport; 2012 [cited 1 October 2012]; Available from: http://www.rijksoverheid.nl/ministeries/vws/documentenen-publicaties?page $=1$. 
54. Egloff M. Studio sul fenomeno degli assicurati morosi. Mandato del Consiglio di Stato; 2009 [cited 7 September 2012]. Available from: www.ti.ch/CAN/SegGC/comunicazioni/GC/odg-mes/allegati/M6275-Allegato.pdf.

55. Kocher G, Oggier W, editors. Gesundheitswesen Schweiz 2007-2009. Bern: Hans Huber; 2007.

56. Federal Council. Botschaft zum Bundesgesetz betreffend die Aufsicht über die soziale Krankenversicherung. 2012 [cited 7 September 2012]. Available from: http://www.bag.admin.ch/themen/krankenversicherung/06368/index.html?lang=de

57. Hefti C, Frey M. Die Entwicklung der Versicherungslandschaft in der Krankenversicherung 1996-2006: Schlussbericht. Neuchâtel: Schweizerisches Gesundheitsobservatoriums; 2008 [cited 8 January 2013]; Available from: www.obsan.admin.ch/bfs/obsan/de/index/05/publikationsdatenbank.Document.113 391.pdf

58. Potratz A, Zerres M. Kundenmanagement in Krankenversicherungen. In: Busse R, Schreyögg J, Tiemann O, editors. Management im Gesundheitswesen. Berlin: Springer-Verlag; 2010. p. 155-62.

59. Zok K. Anforderungen an die Gesetzliche Krankenversicherung: Einschatzungen und Erwartungen aus Sicht der Versicherten [Demands on statutory health insurance: assessments and expectations of insurees]. WIdO monitor. 2009(1):1-8.

60. Schut F, Gresz S, Wasem J. Consumer price sensitivity and social health insurer choice in Germany and the Netherlands. International Journal of Health Care Finance and Economics. 2003;3(2):117-39.

61. Zok K. Reaktionen auf Zusatzbeiträge in der GKV - Ergebnisse einer Repräsentativ-Umfrage. WIdO monitor. 2011(1):1-8.

62. Laske-Aldershof T, Schut FT, Beck K, Gres S, Shmueli A, Van de Voorde C. Consumer mobility in social health insurance markets: a five-country comparison. Applied Health Economics and Health Policy. 2004;3(4):229-41.

63. Vektis. Zorgthermometer: Verzekerden in beweging 2011. Zeist: Vektis; 2011 [cited 20 July 2011]; Available from: http://www.vektis.nl/./downloads/Publicaties/2011/Zorgthermometer\%20nr1\%202 011.pdf.

64. Vektis. Zorgthermometer: Verzekerden in beweging 2012. Zeist: Vektis; 2012 [cited 3 October 2012]; Available from: http://www.vektis.nl/index.php/publicaties/publicatie-zorgthermometer.

65. van Dijk M, Pomp M, Douven R, Laske-Aldershof T, Schut E, de Boer W, et al. Consumer price sensitivity in Dutch health insurance. Int $\mathrm{J}$ Health Care Finance Econ. 2008;8(4):225-44.

66. Comparis.ch. Krankenkassen vergleichen und sparen. Zurich: Comparis.ch; 2011; Available from: http://www.comparis.ch/krankenkassen/default.aspx. 
Table 1 Health insurance coverage, 2011

\begin{tabular}{l} 
Statutory coverage \\
breadth (universality) \\
What \% of the population \\
is not covered? \\
\hline $\begin{array}{l}\text { What are the } \\
\text { characteristics of the } \\
\text { uninsured? }\end{array}$ \\
\hline What is the main role of \\
voluntary health \\
insurance?
\end{tabular}

Coverage scope (benefits) What health services are typically not covered?

\section{Belgium}

Coverage compulsory for all residents since 2008 (salaried workers: 1944;

inpatient care for self employed: 1964;

outpatient care for self employed: 2008)

Less than $1.0 \%$ of the population (a high of $1.4 \%$ in 2007).

Not known (a mixture of people unable premiums).

Supplementary (mainly for superio accommodation in a hospital, not to increase choice or for faster access) and complementary covering eye and dental care.

\section{Broad coverage.}

Eyeglasses and contact lenses, hearing aids, orthodontic care, cosmetic plastic surgery, less necessary drugs (eg overthe-counter drugs and some prescribed drugs such as benzodiazepines) and alternative medicine.

\section{Germany}

Coverage compulsory under SHI since 2007; coverage compulsory for all residents since 2009. Around 85\% covered by SHI, $10 \%$ through PHI, $4 \%$ through other government schemes.

Probably less than $0.5 \%$ of the population (in 2007, before the introduction of compulsory insurance).

Before 2007/09: Self employed, formerly voluntary SHI members, people aged 55 no longer eligible for SHI, divorced women formerly covered as dependants and illegal immigrants.

Substitutive, covering civil servants, selfemployed and high-earning employees who choose private insurance (in total, around $10 \%$ of the population);

complementary, covering user charges and some uncovered services (around $20 \%$ of the population)

Broad coverage.

Eyeglasses, contact lenses and over-thecounter and 'lifestyle' drugs.
Netherlands

Coverage compulsory for all legal residents since 2006.

About $0.2 \%$ of the population in 2012 (plus a further $1.0 \%$ who are illegally resident) (53).

Low-income individuals, both legal and illegal immigrants (illegal immigrants are not allowed to purchase subsidised health insurance)

Complementary, offering mainly dental care and physiotherapy benefits (about $90 \%$ of the population).

\section{Broad coverage.}

Eyeglasses and contact lenses, dental care for adults, orthodontic care,

cosmetic plastic surgery and

alternative medicine.

\section{Switzerland}

Coverage compulsory for all residents since 1996.

About 1.9\% in 2010. New regulations introduced in 2012 should have significantly reduced this percentage (but no official data available yet).

Not known (there was a big debate about whether the uninsured were unable or unwilling to pay health insurance premiums). More likely to be aged 20-59, foreigners, divorced or single, below or just above the threshold for social assistance, users of menta health services (54).

Supplementary cover (offering free choice of hospital across all cantons, free choice of physician in public hospitals, higher standards of hotel comfort in private and semi-private wards, daily cash benefits) and complementary cover of excluded or partially covered services (eg dental care and home care). In 2005 59\% of the population had hospital cover, $37 \%$ had cash benefit cover, $11 \%$ had dental cover and $52 \%$ had cover for other excluded services (55).

Broad coverage.

For eyeglasses and contact lenses only a lump sum is paid. Inpatient care provided at a hospital not on a specific cantonal list, psychotherapy (covered subject to certain conditions), drugs not listed in the 'catalogue of pharmaceutical specialities', alternative medicine, dental care, and cosmetic plastic surgery. 


\section{Belgium}

Who defines the statutory benefits package?

Coverage depth (user
charges)

Who defines user charges policy?
Federal government based on proposals negotiated between sickness funds and providers. The Minster of Social Affairs defines entitlement to drugs based on advice from the Drug Reimbursement Committee.

Co-insurance or co-payments applied to most health services, with an annual outof-pocket maximum.

Federal legislation.

Source: Authors’ research

\section{Germany}

In general terms, federal

providers and patients.

Co-payments for adults applied to most health services, with an annual out-ofpocket maximum.

Federal legislature/parliament. Sickness funds can waive some charges (eg for enrolment in DMPs).

\section{Netherlands}

from the independent Dutch Health

Care Insurance Board (CVZ)

Annual deductible of $€ 220$ (in 2012)

per adult (18+) applied for non-

primary care services.

Central government. Insurers can waive or increase some charges for use of preferred/non-preferred providers. The insured can choose to pay a higher annual deductible.

\section{Switzerland}

Central government based on advice from the Federal Commission on Health Insurance Benefits and General Questions representing payers, providers, patients and scientific advisors.

Minimum annual deductible of CHF 300 (€248) plus co-insurance or co-payments applied to most health services, with an annual out-of-pocket maximum. The maximum optional deductible for adults is CHF 2500 (€2068).

Central government. Insurers may waive or increase some charges. The insured can choose to pay a higher annual deductible.

Note: Curre 
Table 2 Regulation of statutory health insurance, 2012

\begin{tabular}{|l|} 
Who sets and collects \\
contributions? \\
\hline How are statutory health \\
insurance revenues pooled \\
and (re)allocated? \\
\hline Who sets the formula for \\
(re)allocating resources? \\
\hline Who monitors insurer \\
competition?
\end{tabular}

\section{Belgium}

Federal government sets and collects contribution. Sickness funds set and collect additional community-rated premiums.

Income-related contributions and general tax revenue pooled by a central fund and allocated to sickness funds based on a riskadjusted formula and actual costs.

\section{Federal government.}

A government agency (Control Office of the Sickness Funds) and the Belgian Central Bank (NBB). a uniform income-related

\section{Germany}

Since 2011 a national contribution rate has been defined in legislation In 2009/10 the federal government (the cabinet) set a uniform incomerelated contribution rate. Prior to this the sickness funds determined their own contribution rate.

Contributions are collected by

sickness funds but transferred to a central health fund. Sickness funds set and collect additional community-rated premiums.

\section{Income-related contributions and} general tax revenue pooled by a central fund (see note) and allocated to sickness funds based on a risk-adjusted formula.

Parliament defines the principles in law. The Federal Ministry of Health defines the details through ordinance.

SHI: the Federal Insurance Authority; PHI: the Federal Financial Supervisory Authority

Source: Authors’ research

Note: Farmers' sickness funds in Germany do not participate in the central fund and are not subject to the risk equalisation scheme. $\mathrm{PHI}=$ private health insurance; SHI = statutory health insurance; VHI = voluntary health insurance. 
Table 3 Market structure of statutory health insurance, 2012

\begin{tabular}{|c|c|c|c|c|}
\hline & Belgium & Germany & Netherlands & Switzerland \\
\hline What is the legal/profit status of insurers? & $\begin{array}{l}\text { Sickness funds are non-governmental non- } \\
\text { profit organisations under public law. The } \\
\text { market is closed to new entrants. }\end{array}$ & $\begin{array}{l}\text { Sickness funds are non-governmental, non- } \\
\text { profit organisations under public law. }\end{array}$ & $\begin{array}{l}\text { Insurers are private entities } \\
\text { allowed to share profits with } \\
\text { their shareholders. }\end{array}$ & $\begin{array}{l}\text { Insurers are private entities } \\
\text { and cannot share profits on } \\
\text { SHI business. }\end{array}$ \\
\hline $\begin{array}{l}\text { If profit status varies, what is the balance } \\
\text { between non-profit and for-profit? }\end{array}$ & Not relevant. & Not relevant. & $\begin{array}{l}\text { Most insurers are non-profit } \\
\text { mutual associations. }\end{array}$ & $\begin{array}{l}\text { About } 60 \% \text { have non-profit } \\
\text { legal status (foundations or } \\
\text { associations) and } 40 \% \text { are } \\
\text { stock companies owned by } \\
\text { non-profit institutions. }\end{array}$ \\
\hline $\begin{array}{l}\text { If profits are allowed, are there any } \\
\text { controls on profit margins? }\end{array}$ & Not relevant. & No. & No. & $\begin{array}{l}\text { Profits not allowed for SHI } \\
\text { business (see note). }\end{array}$ \\
\hline How many insurers are there? & $\begin{array}{l}\text { Five sickness fund associations (divided } \\
\text { into } 54 \text { local funds), a public insurer of last } \\
\text { resort and a scheme for railroad workers. }\end{array}$ & 146 sickness funds. & $\begin{array}{l}11 \text { health insurance holding } \\
\text { companies in 2010, } 28 \text { different } \\
\text { health insurers in total. The } \\
\text { largest holding company } \\
\text { contains } 7 \text { insurers. }\end{array}$ & $\begin{array}{l}68 \text { insurers involved in SHI in } \\
2012 \text { ( } 8 \text { of which only offer } \\
\text { voluntary daily cash } \\
\text { insurance). }\end{array}$ \\
\hline $\begin{array}{l}\text { What is the market share of the largest } \\
\text { three insurers? }\end{array}$ & About $90 \%$. & About 32\%. & $74 \%$ for holding companies. & $\begin{array}{l}\text { Nationally: } 45 \% \text { (holdings); } \\
\text { 28\% (individual insurers). } \\
\text { Cantonal markets are much } \\
\text { more concentrated. }\end{array}$ \\
\hline $\begin{array}{l}\text { Can insurers who sell SHI also sell } \\
\text { voluntary cover? }\end{array}$ & $\begin{array}{l}\text { Yes, but in } 2010 \text { local sickness fund } \\
\text { compulsory health insurance activity was } \\
\text { separated from VHI activity. From } 2012 \text { the } \\
\text { latter will be offered by non-profit societies } \\
\text { of mutual assistance (part of the national } \\
\text { sickness fund associations). }\end{array}$ & $\begin{array}{l}\text { Sickness funds can broker VHI sold by } \\
\text { private insurers; in practice the line is } \\
\text { becoming blurred as SHI policies for } \\
\text { 'integrated care' include some } \\
\text { supplementary benefits (eg smaller wards in } \\
\text { hospital). }\end{array}$ & $\begin{array}{l}\text { Yes. The Dutch Health } \\
\text { Insurance Act prohibits the } \\
\text { termination of VHI contracts } \\
\text { when enrolees switch to another } \\
\text { insurer for SHI cover. }\end{array}$ & $\begin{array}{l}\text { Yes. Legislation prohibits tied } \\
\text { sales of VHI and SHI. }\end{array}$ \\
\hline
\end{tabular}

Source: Authors' research

Note: In Germany PHI falls under private law. Of the 43 private insurers, 19 are non-profit and 24 are for-profit (2011) and the market share of the largest three insurers is around

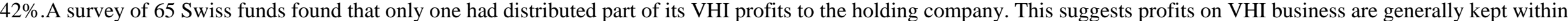
companies to increase reserves, reduce premiums or invest in marketing campaigns (57). PHI = private health insurance; SHI = statutory health insurance; VHI = voluntary health insurance. 
Table 4 Switching rates among enrolees for statutory benefits and characteristics of switchers

\begin{tabular}{|c|c|c|}
\hline Country & Switching rates & Characteristics of switchers \\
\hline Belgium & Early 2000s: around 1\%(14). & No data available. \\
\hline Germany & $\begin{array}{l}\text { 1997-2007: varied from } 4.0 \% \text { to } 5.8 \% \\
\text { (58). }\end{array}$ & $\begin{array}{l}\text { 1995-2001: switchers more likely to be younger and } \\
\text { healthier (25, 28, 59, 60); 2010: switchers more likely to } \\
\text { be younger, higher income, better educated and not } \\
\text { chronically ill (61). }\end{array}$ \\
\hline Netherlands & $\begin{array}{l}\text { Before 2000: around 1\% (62); 2005: } \\
\text { around 3\% (8); 2006: 18\%; 2007: 4.4\%; } \\
\text { 2008: 3.6\%; 2009: 3.5\% (26); 2010: 5.5\% } \\
\text { (63); } 6.0 \% \text { in } 2011 \text { (64). }\end{array}$ & $\begin{array}{l}\text { Prior to 2006: switchers more likely to be younger and } \\
\text { better educated }(25,65) ; 2006-2009 \text { : switchers have better } \\
\text { self-reported health }(26) \text {. }\end{array}$ \\
\hline Switzerland & $\begin{array}{l}\text { Switching rates fell from } 4.8 \% \text { in } 1997 \text { to } \\
2.1 \% \text { in } 2000 \text { (23) and rose from } 12 \% \text { in } \\
2008 / 9 \text { to } 15.4 \% \text { in } 2009 / 10 \text { ( } 25 \% \text { among } \\
\text { those choosing the largest annual } \\
\text { deductible) (66). }\end{array}$ & $\begin{array}{l}\text { 1996-2005: switching more likely among people choosing } \\
\text { higher deductibles, less likely with age and less likely } \\
\text { among people with VHI whose self-reported health is } \\
\text { 'poor' or 'good' (as opposed to 'very good') (20); 2000: } \\
\text { switching less likely among people with VHI (23). }\end{array}$ \\
\hline
\end{tabular}

Source: Authors' research

Note: VHI = voluntary health insurance.

Table 5 Price and quality differences between insurers

\begin{tabular}{|l|l|}
\hline Country & Is price a reason for switching? \\
\hline Belgium & $\begin{array}{l}\text { No. Price differences are negligible. In } 2010 \\
\text { additional community-rated premiums did not exceed } \\
€ 20 \text { per enrolee per year. Price elasticity }<1(62) .\end{array}$ \\
\hline
\end{tabular}

\begin{tabular}{|c|c|}
\hline Germany & $\begin{array}{l}\text { Yes. In the late 1990s substantial differences in } \\
\text { contribution rates across insurers and the role of } \\
\text { employers in financing coverage led to high price } \\
\text { elasticity }(60,62) \text {. Since } 2009 \text {, with the introduction } \\
\text { of the nationally uniform contribution rate, price } \\
\text { signals have generally been weak, but people are } \\
\text { very sensitive to price where signals exist. }\end{array}$ \\
\hline
\end{tabular}

Netherlands Yes. Negligible price differences before 2006. Since 2006 insurers differentiate themselves through premium discounts for higher deductibles or group coverage.

\begin{tabular}{|c|c|}
\hline Switzerland & $\begin{array}{l}\text { Yes. Substantial variation in premiums; insurers } \\
\text { differentiate themselves through discounts for } \\
\text { children under } 18 \text {, students aged } 19-25 \text {, enrolees who } \\
\text { opt for higher deductibles (up to } 70 \% \text { of difference } \\
\text { between the minimum and the chosen deductible) or } \\
\text { managed-care contracts (up to } 20 \% \text { ). }\end{array}$ \\
\hline
\end{tabular}

\section{Is quality a reason for switching?}

Yes. People switch to be with the same insurer as a partner, for better customer service or to obtain a different set of VHI benefits (the main reason).

Yes. The reasons given for switching include better benefits, better service, better image and change of employer or industry (59). In 2010 additional care offers were also mentioned (61).

Yes. Little product differentiation before 2006. Greater differentiation since 2006 in terms of the range of prescription drugs reimbursed within a given therapeutic category, modes of customer service and VHI products.

Yes. People can opt for managed-care contracts involving gatekeeping and preferred provider networks.

Source: Authors' research

Note: VHI = voluntary health insurance. 
Table 6 Choice for users, 2012

\begin{tabular}{|c|c|c|c|c|}
\hline Choice regarding: & Belgium & Germany & Netherlands & Switzerland \\
\hline $\begin{array}{l}\text { Insurance status (to } \\
\text { be insured or not) }\end{array}$ & No. & No. & No. & No. \\
\hline Insurers & $\begin{array}{l}\text { Yes. After } 12 \text { months } \\
\text { of enrolment, people } \\
\text { can switch quarterly. }\end{array}$ & $\begin{array}{l}\text { Yes. People can switch } \\
\text { after } 18 \text { months or within } 2 \\
\text { months if the insurer } \\
\text { introduces or raises a } \\
\text { community-rated } \\
\text { premium. }\end{array}$ & $\begin{array}{l}\text { Yes. People can } \\
\text { switch once a } \\
\text { year. }\end{array}$ & $\begin{array}{l}\text { Yes. People can switch } \\
\text { twice a year giving } \\
\text { three months' notice. }\end{array}$ \\
\hline $\begin{array}{l}\text { Level of pre-paid } \\
\text { contribution }\end{array}$ & $\begin{array}{l}\text { Yes, for community- } \\
\text { rated premiums, but } \\
\text { the amounts are } \\
\text { negligible. }\end{array}$ & $\begin{array}{l}\text { Yes, for the community- } \\
\text { rated premium (but this is } \\
\text { currently very small). }\end{array}$ & $\begin{array}{l}\text { Yes, for } \\
\text { community- } \\
\text { rated premiums. }\end{array}$ & Yes. \\
\hline Range of benefits & No. & $\begin{array}{l}\text { No, except for a very few } \\
\text { benefits defined by } \\
\text { individual sickness funds. }\end{array}$ & No. & No. \\
\hline $\begin{array}{l}\text { Benefit modality } \\
\text { (cash vs in kind) }\end{array}$ & No. & Yes & Yes. & No. \\
\hline $\begin{array}{l}\text { Extent of user } \\
\text { charges }\end{array}$ & $\begin{array}{l}\text { Only in conjunction } \\
\text { with other conditions } \\
\text { (eg use of generic } \\
\text { drugs, use of regular } \\
\text { GP, gatekeeping). } \\
\text { Same for all sickness } \\
\text { funds. }\end{array}$ & $\begin{array}{l}\text { Only in conjunction with } \\
\text { other conditions (eg } \\
\text { gatekeeping, enrolment in } \\
\text { DMP). Varies by sickness } \\
\text { fund. }\end{array}$ & Yes. & Yes. \\
\hline Providers & Yes. & Yes. & Yes. & Yes. \\
\hline
\end{tabular}

Source: Authors' research

Note: GP = general practitioner; DMP = disease management programme.

Table 7 Strength of insurer incentives to select risks, 2012

\begin{tabular}{|c|c|c|c|c|}
\hline & Belgium & Germany & Netherlands & Switzerland \\
\hline $\begin{array}{l}\text { Prospective resource } \\
\text { allocation subject to risk } \\
\text { equalisation }(\%)\end{array}$ & $30 \%$ & $100 \%$ & $100 \%$ & $100 \%$ \\
\hline Risk equalisation scheme & Yes. & Yes. & Yes. & Yes. \\
\hline $\begin{array}{l}\text { Risk adjustment includes } \\
\text { health-based criteria }\end{array}$ & Yes. & Yes. & Yes. & $\begin{array}{l}\text { Partially (hospitalisation of at least } 3 \\
\text { days in the previous year); plans to } \\
\text { include additional health-based criteria. }\end{array}$ \\
\hline Risk sharing & $\begin{array}{l}\text { Insurers pay } 25 \% \\
\text { of any revenue- } \\
\text { expenditure gap. }\end{array}$ & No. & No. & No (see note). \\
\hline Incentive to select risks & Low. & High. & High. & Very high. \\
\hline
\end{tabular}

Source: Authors' research

Note: Swiss insurers bear full financial risk for outpatient care, but the costs of inpatient care are shared between insurers and cantons. 
Table 8 Regulation of insurer-provider relations, 2012

\begin{tabular}{|c|c|}
\hline & Belgium \\
\hline $\begin{array}{l}\text { Who regulates } \\
\text { purchaser-provider } \\
\text { relations? }\end{array}$ & $\begin{array}{l}\text { Basic framework established through } \\
\text { federal legislature. Organised at the } \\
\text { federal level through collective } \\
\text { negotiation between provider and } \\
\text { sickness fund representatives. }\end{array}$ \\
\hline $\begin{array}{l}\text { Describe the main } \\
\text { characteristics of } \\
\text { purchaser-provider } \\
\text { relations }\end{array}$ & $\begin{array}{l}\text { Fee schedule determined through } \\
\text { collective negotiation among sickness } \\
\text { funds / provider groups. Agreements } \\
\text { negotiated for two years. Increasingly, } \\
\text { physicians opt out of the agreements } \\
\text { (13\% of GPs, } 20 \% \text { of specialists, with } \\
\text { large differences among specialists). } \\
\text { Selective contracting not allowed. }\end{array}$ \\
\hline $\begin{array}{l}\text { Are there caps on } \\
\text { insurer } \\
\text { administrative costs? }\end{array}$ & $\begin{array}{l}\text { Yes. The cap is determined annually } \\
\text { by federal law (programme law). }\end{array}$ \\
\hline $\begin{array}{l}\text { Who determines how } \\
\text { providers are paid? }\end{array}$ & $\begin{array}{l}\text { All payment mechanisms are set out in } \\
\text { federal legislation. }\end{array}$ \\
\hline $\begin{array}{l}\text { Who sets health } \\
\text { service prices? }\end{array}$ & $\begin{array}{l}\text { Collective negotiation between } \\
\text { provider/sickness fund representatives, } \\
\text { approved by Minister of Social Affairs. } \\
\text { Maximum price of pharmaceuticals set } \\
\text { by Minister of Economic Affairs based } \\
\text { on advice from a commission of trade } \\
\text { unions, pharmacists, sickness funds, } \\
\text { pharmaceutical industry, government. }\end{array}$ \\
\hline $\begin{array}{l}\text { Changes in any of the } \\
\text { above }\end{array}$ & No. \\
\hline
\end{tabular}

\section{Germany}

Basic framework established through federal legislature. Details negotiated among corporatist actors at the federal level with federal Ministry of Health oversight, and at state level with state ministries responsible for health.

Social law stipulates the areas in which decision must be made by joint committees of sickness funds and providers (eg SHI benefits and the relative point value scale for SHI-accredited physicians), and those in which decisions can be reached through direct negotiations (total level of remuneration for ambulatory care and contracts between funds and providers).

Yes (since 2004). The cap used to apply to administrative costs as a percentage of expenditure; for 2011 capped at the 2010 level.

Federal legislation increasingly sets out payment mechanisms, but details are decided by corporatist actors.

Ambulatory care: federal and state corporatist institutions (sickness funds and Federa Association of SHI Physicians) $D R G s$ : federal corporatist institutions (sickness funds and German Hospital Federation) and federal government if no agreement. Pharmaceutical reference prices: corporatist institutions at federal level, but manufacturers generally free to determine prices.

Since 2011 pharmaceuticals demonstrating clinical added value and those that cannot be included in the reference pricing system have been subject to price negotiations between manufacturers/sickness funds a year after launch.

\section{Netherlands}

The Dutch Healthcare Authority and the Dutch Competition Authority.

ing for physiotherapy since 2005 and for selected inpatient services. Selective contracting and vertical integration allowed since 2006. Insurers and providers are free to choose tools for managing care.

No.

A combination of government and free price negotiation between insurers and providers.

Government price setting and free price negotiation between insurer and providers. The prices of onethird of all hospital products (which include doctors' fees) are set by the government, and the government sets maximum prices for most GP services.

Insurers and providers have more freedom to negotiate prices. This trend is expected to continue.

\section{Switzerland}

National legislation (FHIA) defines genera rules. Hospital sector strongly regulated and planned by the 26 cantonal authorities. Outpatient care regulated through the TARMED tariff scheme. In 2002 the Federal Council decreed a moratorium on the opening of new medical practices (delegating this to the cantons), which was extended to end 2009 for GPs and end 2011 for specialists.

Insurers must reimburse all medical service prescribed by physicians and contract all hospitals included in cantonal planning and any physician permitted to practise, giving patients the right to visit any outpatient physician without registration or referral. Selective contracting and capitation payment are allowed for patients opting for managed-care plans. No.

National legislation (FHIA) sets out general rules for provider payment.

Mainly collective negotiation between insure and provider representatives approved by government. Cantonal authorities set prices if agreement cannot be reached. Pharmaceutical and laboratory prices set by the federal government.

No.

Source: Authors’ research

Note: GP = general practitioner; $\mathrm{SHI}$ = statutory health insurance 
Table 9 Availability and take-up of purchasing tools by insurers offering statutory benefits, 2012

\begin{tabular}{|c|c|c|c|c|}
\hline Tools & Belgium & Germany & Netherlands & Switzerland \\
\hline $\begin{array}{l}\text { Vertical insurer- } \\
\text { provider integration }\end{array}$ & Yes; take-up very low.. & $\begin{array}{l}\text { No, with rare historical exceptions; otherwise } \\
\text { only permitted for rehabilitation. }\end{array}$ & $\begin{array}{l}\text { Yes; take-up low but } \\
\text { growing. }\end{array}$ & $\begin{array}{l}\text { Yes, but take-up low; an attempt to ban vertical integration of } \\
\text { insurer and providers was rejected by popular ballot, along } \\
\text { with a proposal for integrated care networks, in } 2012 \text {. }\end{array}$ \\
\hline Selective contracting & No. & $\begin{array}{l}\text { Yes, but only in the context of integrated care } \\
\text { contracts, therefore low take-up. }\end{array}$ & $\begin{array}{l}\text { Yes; take-up low but } \\
\text { growing strongly. }\end{array}$ & $\begin{array}{l}\text { Yes, but only for enrolees opting for managed-care contracts } \\
\text { ( } 46 \% \text { of the population in 2010); however, only part of these } \\
\text { contracts are genuinely based on selective contracting. }\end{array}$ \\
\hline $\begin{array}{l}\text { Financial incentives for } \\
\text { patients to use } \\
\text { preferred providers }\end{array}$ & No. & $\begin{array}{l}\text { Yes; moderate take-up (GP contracts less } \\
\text { popular than expected). }\end{array}$ & $\begin{array}{l}\text { Yes; take-up low but } \\
\text { growing strongly. }\end{array}$ & $\begin{array}{l}\text { A } 15 \% \text { co-insurance rate for ordinary coverage and a } 10 \% \\
\text { rate for plans with preferred providers and integrated care } \\
\text { networks was approved by parliament but cancelled } \\
\text { following the referendum held in June } 2012 \text {. }\end{array}$ \\
\hline $\begin{array}{l}\text { Clinical guidelines / } \\
\text { protocols }\end{array}$ & Yes, collectively. & $\begin{array}{l}\text { Yes, possible within GP contracts and integrated } \\
\text { care contracts; low take-up. }\end{array}$ & $\begin{array}{l}\text { Yes; moderate to high take- } \\
\text { up. }\end{array}$ & $\begin{array}{l}\text { Not explicitly. It is up to the physicians to use these tools to } \\
\text { deal with eg capitation payment within managed-care } \\
\text { contracts. }\end{array}$ \\
\hline $\begin{array}{l}\text { Formularies for } \\
\text { medicines }\end{array}$ & Yes, collectively. & $\begin{array}{l}\text { Yes, possible within GP contracts and integrated } \\
\text { care contracts; low take-up. }\end{array}$ & Yes; moderate take-up. & $\begin{array}{l}\text { No. Pharmaceuticals included in the benefits package cannot } \\
\text { be restricted through managed-care arrangements. }\end{array}$ \\
\hline $\begin{array}{l}\text { Incentives for rational } \\
\text { prescribing / dispensing } \\
\text { of medicines }\end{array}$ & Yes, collectively. & $\begin{array}{l}\text { Directed at physicians: prescription limits; } \\
\text { directed towards pharmacists: generic } \\
\text { substitution unless ruled out; directed at patients: } \\
\text { lower co-payments for drugs priced at least } 30 \% \\
\text { below reference price. }\end{array}$ & $\begin{array}{l}\text { Financial incentives to } \\
\text { pharmacists to encourage } \\
\text { generic substitution. }\end{array}$ & $\begin{array}{l}\text { A higher co-insurance rate ( } 20 \% \text { rather than } 10 \% \text { ) for brand } \\
\text { drugs if a generic alternative is available. }\end{array}$ \\
\hline $\begin{array}{l}\text { Disease management } \\
\text { programmes }\end{array}$ & Yes, collectively. & $\begin{array}{l}\text { Yes; high take-up (about } 9 \% \text { of SHI enrolees in } \\
\text { 2011). }\end{array}$ & $\begin{array}{l}\text { Yes; take-up low but } \\
\text { growing. }\end{array}$ & Not explicitly. \\
\hline Utilisation review & $\begin{array}{l}\text { Yes, collectively, but only for } \\
\text { very expensive services. }\end{array}$ & $\begin{array}{l}\text { Yes, collectively and routinely; individually only } \\
\text { in integrated care contracts, low take up. }\end{array}$ & Yes; moderate take-up. & Yes, within managed-care arrangements. \\
\hline $\begin{array}{l}\text { Waiting list } \\
\text { management }\end{array}$ & Not relevant. & Not relevant. & $\begin{array}{l}\text { Yes; high take-up and } \\
\text { successful. }\end{array}$ & Not relevant. \\
\hline Price negotiation & No. & $\begin{array}{l}\text { Yes, partial (eg GP-based gatekeeping or } \\
\text { integrated care contracts); currently mainly with } \\
\text { pharmaceutical manufacturers, high take up } \\
\text { (about } 60 \% \text { of drugs distributed under rebate } \\
\text { contracts). }\end{array}$ & Yes, partial; high take-up. & Yes, but only for enrolees opting for managed-care contracts. \\
\hline $\begin{array}{l}\text { Performance-based } \\
\text { payment of providers }\end{array}$ & No & $\begin{array}{l}\text { Yes, but used only within integrated care } \\
\text { contracts; low take up. }\end{array}$ & $\begin{array}{l}\text { Yes, partial; take-up } \\
\text { growing. }\end{array}$ & Yes, within managed-care arrangements. \\
\hline $\begin{array}{l}\text { Public disclosure of } \\
\text { performance indicators }\end{array}$ & $\begin{array}{l}\text { Yes, collectively, mainly for } \\
\text { supplementary hospital costs }\end{array}$ & $\begin{array}{l}\text { Yes; mandatory for certain hospital indicators } \\
\text { (but not very relevant for purchasing). }\end{array}$ & $\begin{array}{l}\text { Yes; moderate take-up but } \\
\text { growing. }\end{array}$ & Yes, in the hospital sector; modest results. \\
\hline
\end{tabular}

Source: Authors' research

Note: GP = general practitioner; SHI = statutory health insurance. 